\author{
Textbook: Focus on Students' National Identity
}

\title{
Foreign language Internet environment and its impact on cultural self-determination of students.
}

\author{
Nataliia E. Merkish (a)* \\ (a) Moscow MGIMO University, 119454, Moscow (Russia), 76, Vernadsky prospect, \\ merkisch@hotmail.com
}

\begin{abstract}
The relevance of the problem.

In modern language education, Internet resources are intensively used, which together create a cultural and linguistic Internet environment. This environment can be defined as a virtual space in which the perception of information and the exchange of it is realized. It seems relevant to consider the issues of the influence of the Internet environment used in the process of learning foreign languages on the formation of a student's personality, and, in particular, his national and cultural self-determination.

\section{Purpose of the article.}

The empirical research was carried out in the process of teaching German as a second foreign language to international students of the 4th year of MGIMO. Its purpose was to consider the problem of the influence of the Internet environment on the cultural self-determination of students.

\section{Methodology.}

When conducting an empirical study of the influence of the Internet environment on self-determination of students, the author used methods of analysis of scientific and theoretical sources, analysis and systematization of empirical experience.

Results. The study identified the advantages and controversial aspects of using the Internet environment. In order to neutralize the influence of the environment, the following recommendations were formulated: the use of pluralism of the information space, the development of critical thinking skills, the need to teach students the basics of culturalcritical analysis of the source.

Keywords: foreign language Internet environment, teaching foreign languages, cultural self-determination of students
\end{abstract}

\section{(C) 2021 Nataliia E. Merkish}

This is an open access article distributed under the terms of the Creative Commons Attribution License (CC BY 4.0), which permits unrestricted use, distribution, and reproduction in any medium, provided the original author and source are credited.

Published by Moscow City University and peer-reviewed under responsibility of TSNI-2021 (Textbook: Focus on Students' National Identity)

\footnotetext{
* Corresponding author. E-mail: merkisch@ hotmail.com
} 


\section{Introduction.}

The modern period is characterized by a significant increase in the share of Internet resources used in the process of learning foreign languages. The global Internet environment today accumulates a significant part of the knowledge accumulated by mankind. It is no coincidence that the expansion of the multilingual and multicultural Internet space is called one of the main trends in the current period of history [Safonova, 2014, p. 124].

Internet sources used in the process of teaching a foreign language, in their totality, create an Internet environment, that is, a virtual space in which the perception and exchange of information is realized. This environment, like any other environment in which a person falls, has a certain influence on him. Ideas, values, present in the virtual space, are appropriated to the learners to one degree or another. It seems that being in an artificially created cultural and linguistic environment, as well as being in a real environment, contributes to the process of acculturation of the individual, understood as a change in value orientations, role behavior, social attitudes [Sadokhin, 2004, p.116]. Consequently, today it seems relevant to consider the issues of the influence of the Internet environment and the Global Information Network, used in the process of learning foreign languages, on the process of forming a student's personality, and, in particular, his national and cultural self-determination.

The Internet environment is global in nature and carries information in almost all languages of the world. Knowing a foreign language, a person enters a new information sphere for him, and a good command of several foreign languages makes a person a full-fledged participant in several cultural worlds. At the same time, the worlds of foreign languages often compete with the world of the native language, create a new picture of the world, operate with other value orientations.

Under these conditions, the question of the national and cultural self-determination of students, understood by researchers as the awareness of oneself as a carrier of some socially significant features among the surrounding cultural diversity, becomes relevant. [Milrud, 2016, p. 404]. In other words, cultural self-determination is the awareness of one's belonging to a specific culture and a specific linguistic society. The problem of cultural self-determination is closely related to the issue of students' awareness of their own cultural identity, which can be presented as the core of the personality, without which it is easily lost in the diversity of languages and cultures of the global world.

\section{Purpose and objectives of the study.}

The aim of the empirical study, carried out in teaching German as a second foreign language to the 4th year international students at MGIMO, was to consider the problem of the influence of the Internet environment on the cultural self-determination of students. The study was conducted over two semesters. It solved the following tasks:

- Analysis of the expediency of using the Internet environment in the process of teaching foreign 
languages: identifying the advantages and controversial aspects of its application, as well as factors affecting the cultural self-determination of students;

- Development of an algorithm for analyzing a foreign language media source, as well as recommendations aimed at neutralizing the influence of the Internet environment on the cultural selfdetermination of students.

\section{Literature review}

A significant amount of research has been devoted to the problem of using Internet resources in foreign language education. Despite the fact that the problem has been discussed in linguodidactics for a quarter of a century, its relevance is not diminishing. A large number of works have appeared on the analysis of the current state of the process of teaching foreign languages. The problem of assessing professional communicative competence [Tareva \& Tarev, 2018] is investigated, an analysis of innovative teaching methods [Belyaeva, Samorodova, Voron, Zakirova, 2019] is given, and the tools for assessing learning outcomes [Shamov, Guseva, 2017] are discussed. In studies devoted to computational linguodidactics, the main directions of informatization of the educational process [Sysoyev, 2015], the problems of media competence and literacy [Festl, 2021], the didactic capabilities of Internet resources [Severova, Myuller, 2020], trends in media consumption in the context of digitalization [Tretyakova, Karakozov, Voevoda, 2019], psychophysiological processes of perception of digital information [ Baiguzhin, Shibkova, Aizman, 2019]. More specific issues include a discussion of the selection and typology of digital media [Bartosh, Galskova, Kharlamova, Stoyanova, 2020; Lewalter, Walper, 2021], motivation [Senkbeil, 2017] and autonomy [Jakovleva, 2016] in digital learning, a discussion of distance teaching experience in a pandemic [Voss, Wittwer, 2020; Anger, Plünnecke, 2020; Savankova, Hosainova, Chigasheva 2020].

These studies are aimed at developing methodological issues of teaching foreign languages in the changed conditions of the global world, which has entered modern life through the World Wide Web. Despite the significant amount of work, many problems of learning with the involvement of Internet resources, as well as its influence on the formation of a person, still need to be addressed.

\section{Methodology.}

In the course of the research, methods of analysis of scientific and theoretical sources, analysis and systematization of empirical experience were used.

\section{Results.}

1. Analysis of the expediency of using the Internet environment in the process of teaching foreign languages: identifying the advantages and controversial aspects of its use, as well as factors affecting the cultural self-determination of students.

Teaching foreign languages has always differed from teaching other subjects of the humanitarian cycle. A foreign language is closely related to a foreign language culture. And culture, like language, is a living 
matter, which is extremely difficult to master in isolation from the cultural and linguistic environment. In this regard, the Internet is considered as a one-of-a-kind source of information and a teaching tool that allows you to model the cultural and linguistic environment for educational purposes. The main type of activity carried out while in a foreign-language Internet environment should be considered the reception of oral and written texts. However, the modern possibilities of the Internet allow the production of written and oral speech in a foreign language.

As a result of the empirical study, the expediency of creating an Internet environment was analyzed and a number of advantages of its use as a means of teaching foreign languages were identified:

- immersion in the digital environment is possible at any convenient moment in the student's academic or extracurricular time;

- when using the media environment, indirect communication is realized in the foreign language being studied, in which information comes to the student not directly, from the source, but through technical means. With all the differences from direct or natural communication, this type of activity has a positive effect on the development of skills and abilities of the target language;

- media texts presented in the Internet environment are relevant, diverse in style and genre characteristics, are both monologic and dialogical, and are implemented in written and oral speech. This makes them one of the main means of teaching a foreign language, especially at an advanced stage;

- when immersed in the Internet environment, several channels of information are involved - auditory and visual, which is certainly important when studying a foreign language;

- being in a foreign-language Internet environment has a positive effect on the development of all types of speech activity and aspects of the language;

- attraction of video texts as a source of linguistic and extralinguistic information has a positive effect on the development of students' verbal and non-verbal speech;

- the video sequence used ensures the emotional nature of the perception and assimilation of information, which contributes to the formation of emotive competence [Chernyshov, 2014];

- both educational and independent immersion affects the motivation to learn a foreign language and the culture of its speakers.

In the process of conducting empirical research, controversial aspects of using the Internet environment were also identified. Immersion in a foreign language digital environment was realized in foreign language classes, in the preparation of homework assignments, as well as in students' independent work. Do not discount the time allotted for work on the first foreign language. In addition, students read foreign media texts presented in the Russian-language segment of the network, and MGIMO students of an advanced level do not even consider the reception of foreign-language sources to be work on the language, and move freely on the vastness of the foreign-language Internet in search of information that interests them. Such 
daily many hours of stay in a foreign cultural environment gradually affects the process of cultural identification, changes the structure of the student's personality.

It is no secret that the bulk of modern sources of the global network explicitly or implicitly propagandize the ideology of consumption and individualism. In addition, contradictions often arise between the point of view of foreign-language and Russian-language media on economic and political issues on the agenda. Today the media are a weapon in the information war, and researchers talk about the ongoing war of cultures and civilizations.

On the one hand, one should not overestimate the influence of the foreign language media environment on the formation of the personality of students. Students are in their home country, in a familiar environment, surrounded by facts of their native culture, people belonging to the same culture and creating a kind of "frame" of individuals who share common values. They are not abandoned at a young age into the ocean of a foreign culture, in which their future life will proceed. On the other hand, according to researchers, the formation of cultural identity ends only at the age of 18-25. That is, university students are still influenced and can gradually change the priorities, values, guidelines and rules of interpersonal interaction learned from childhood. Subject to changes and assessments of the surrounding reality, events and facts of historical heritage.

2. Development of an algorithm for analyzing a foreign language media source, as well as recommendations aimed at neutralizing the influence of the Internet environment on the cultural self-determination of students.

In the process of the empirical research conducted, the students worked with the German-language media presented in the form of print, audio and video materials. The reception of media texts, work on the content side and lexical and grammatical means were carried out. The final stage of working with the text was its oral or written abstracting. In addition, group discussions were held to facilitate the comprehension of the cultural information of the text.

The empirical research involved 4th year MGIMO students studying German as a second foreign language. At this stage of training, socio-political issues are considered, in connection with which the texts used were devoted to the economic, political and cultural problems of modern Germany. Particular attention was paid to the analysis of the influence of the media on the cultural self-determination of students and the problems of its neutralization.

The Internet environment used in teaching certainly influences the structure of a student's personality. The teacher's task is to weaken this influence by developing students' critical thinking, as well as the skills of analyzing incoming information and its verification, that is, comparing with other sources. An important stage is the identification of the evaluative component explicitly or implicitly contained in the material, its study and correlation with one's own position. Thus, we have developed a step-by-step methodology for 
analyzing a foreign language media source with the aim of leveling its influence on the cultural selfdetermination and identity of students.

As an initial stage of work, it seems expedient to study and evaluate the mass media itself - a newspaper, magazine or TV and radio company that has published a media text perceived by students. The main points of this analysis will be finding information about the reputation of the publication, its owner, proximity to political parties and movements. It is necessary to explain to students that even with an independent immersion in the cultural and linguistic environment, it is preferable to use information from well-known media, since in this case one can assume the degree of reliability of the information, the angle of consideration of the problems presented, and popularity in the German-speaking society. The teacher can advise students on the degree of popularity of specific media in Germany, their topics, and target audience. This information is extremely important for navigating the world of modern media in Germany, creating a kind of scale or axis of coordinates on which the student will mentally place the media familiar to him, based on the criteria listed above.

Further analysis focuses directly on the media text itself. As a first step, consider the subject matter of the text. This will allow to outline the approximate range of the problems touched upon, thus designating a fragment of the picture of the world, objectified in a foreign language message. Revealing the problematic allows you to update the information stock of students during the pre-text stage of work and prepares them for the perception of the text.

The next step is aimed at analyzing the historical period of writing the text, or considering the most pressing problems of the modern period related to the stated problems. In addition, it is necessary to discuss the event itself, which was the reason for the creation of the text. These moments of analysis can be described as the study of the historical and event context.

Further analysis involves identifying the main cultural realities of the message and discussing their role in contemporary German culture. Key concepts of the media text are commented on, their culturally specific information is revealed, thus the background knowledge of students is replenished.

A necessary aspect of the critical study of the text is the analysis of hypotheses and argumentation of the personified source of information, that is, the author. What are the reasons for the conclusions proposed in the article, what are the main proofs of the stated version of events and processes? Students should be taught to formulate questions to the creator of the text. Thus, objectification of the offered information is achieved, the emotional impact of the text is reduced, the source seems to move away from the recipient, and meaningful information devoid of subjectivity comes to the fore.

In addition, it is necessary to focus the attention of students on the use of ideologized structures and manipulative techniques in communication. It is known that media materials, like advertising, can have a certain impact on the recipient. So, it is possible to impose evaluative scenarios, influence on the 
consciousness and subconsciousness of the individual. Most of the texts carry an explicit or implicit assessment, which is why it is so important to train future international specialists in filtering factual information and neutralizing the text as a source of a certain ideology and picture of the world.

In addition, it is preferable to compare the source with other documents in a foreign or native language of students. Such a comparison and comparison is called verification, it allows you to identify mismatched aspects of publications and discuss their reasons. Using sources in Russian, we arrange the so-called dialogue of cultures, which is realized in correspondence discussion of representatives of several cultural formations. The recipient of messages can in this case be considered as a third party, building in the process of such a "dialogue" its own rating of trust to sources.

In the process of the described critical analysis of the source of information, the student's personal position on the problem under consideration is built, arguments are collected to prove his own opinion. The student learns to draw conclusions and formulate them in a foreign language.

Learning lexical and grammatical means of expressing thoughts is also an important stage in working with a source of information. Otherwise, the student uses the linguistic material of the text, taking over together with linguistic means not only the factual, but also the evaluative aspect of the message.

In the course of the empirical research, special attention was paid to cases of mismatch in the value orientations of authors and students, options for students to find strategies for getting out of this situation, as well as their use of lexical and grammatical means to convey the content of the text and express their own opinion. Of particular interest was the analysis of the results of abstracting media texts by students, which used terminology and statements that did not coincide with the picture of the world of a native Russian speaker. Based on the experience of the research, we consider it expedient to formulate questions in advance in the pre-text task aimed at identifying the personal position of students and, if necessary, suggest keywords and phrases that they can use when abstracting the article and expressing their own opinion.

\section{Discussion}

The study has shown that the Internet environment can have a significant impact on the cultural selfdetermination of students. The intensity of this influence depends on the time spent by the student in a foreign language cultural and linguistic environment, the age of the recipients, the mental properties of the personality, the degree of formation of worldview attitudes and other factors. In order to neutralize the influence of the Internet environment, some recommendations were formulated. We believe that one of the main recommendations is the need to teach students to use the pluralism of the information space, that is, to involve several sources in a foreign and native language for information verification. The next necessary step is the development of students' critical thinking skills, which allows them to build a coherent system of judgments for assessing the facts, events and processes of the surrounding reality. And finally, the final 
point is the need to teach students the basics of cultural-critical analysis of the source, which includes the following stages:

- assessment of a media source (newspaper, magazine or TV and radio company) from the position of its reputation in a foreign-language society, proximity to political movements and parties, topics and target audience;

- assessment of the media text problem;

- assessment of the historical and eventual context of writing an article or creating a video material;

- identifying and mastering the main cultural realities of the text;

- checking hypotheses and argumentation of the author;

- detection of ideologized structures and manipulative techniques in the source text;

- comparison of message information with other foreign-language or Russian-language sources, that is, its verification;

- the formation of the student's personal position on the issue under consideration;

- teaching lexical and grammatical means of formulating a statement, expressing one's own position and criticizing mismatched aspects of the value system and the picture of the world.

\section{Conclusion.}

The implementation of the proposed recommendations in practice will allow students to master culturally-specific information that is important for them, to understand the picture of the world of the people, to get acquainted with the system of value orientations. At the same time, the student remains a native speaker of the Russian language and native culture, which is the basis for the development of his personality. He retains his cultural identity, but, thanks to the knowledge gained, he is ready for a productive dialogue with a native speaker of the target language.

\section{References}

Anger, C., Plünnecke, A. (2020). School education in times of the corona crisis [Schulische Bildung zu Zeiten der Corona-Krise]. Perspektiven der Wirtschaftspolitik , 21(4), 353-360. Retrieved from: https://doi.org/10.1515/pwp-2020-0055

Baiguzhin, P.A., Shibkova, D.Z., Aizman R. I. (2019). Faktory, vliyayushchie na psihofiziologicheskie processy vospriyatiya informacii v usloviyah informatizacii obrazovatel'noj sredy [Factors affecting psychophysiological processes of information perception within the context of education informatization]. Science for Education Today, 9 (5), 48-70. Retrieved from: https://doi.org/10.15293/2658-6762.1905.04

Bartosh, D., Galskova, N.D., Kharlamova, M., Stoyanova, E. (2020). Cifrovye sredstva v obuchenii inostrannym yazykam: otbor i tipologizaciya [Digital Means in Foreign Language Teaching: 
Selection and Typologization]. Obuchenie inostrannym yazykam [Foreign languages teaching], 47 (4), 340-351. Retrieved from: https://www.elibrary.ru/item.asp?id=44164377

Belyaeva, I. G., Samorodova, E. A., Voron, O. V., Zakirova, E. S. (2019). Analysis of innovative methods' effectiveness in teaching foreign languages for special purposes used for the formation of future specialists' professional competencies. Education Sciences, 9 (3). Retrieved from: https://doi.org/10.3390/educsci9030171

Chernyshov, S.V. (2014). Emocional'nyj aspekt soderzhaniya obucheniya inostrannym yazykam [Emotional aspect of the foreign language teaching content]. Yazyk i kul'tura [Language and Culture] ,4, 73-79. Retrieved from: https://www.elibrary.ru/item.asp?id=23310273

Festl, R. (2021). Social media literacy among adolescents - The role of knowledge, motivation and abilities for a socially competent behavior online [Soziale Medienkompetenz von Jugendlichen - Zur Rolle von Wissen, Motivation und Fähigkeiten für ein sozial kompetentes Handeln online]. Psychologie in Erziehung und Unterricht, 68 (1), 58-73. Retrieved from: http://dx.doi.org/10.2378/peu2021.art04d

Jakovleva, T.A. (2016). Avtonomnoe obuchenie [Offline learning]. Jazyk, kul'tura, kommunikacija: izuchenie i obuchenie. Materialy I Mezhdunarodnoj nauchno-prakticheskoj konferencii [Language, culture, communication: learning and teaching. Materials of the I International Scientific and Practical Conference], 107-111. Retrieved from: https://www.elibrary.ru/item.asp?id=27336311

Lewalter, D., Walper, S. (2021). Kompetenzen und Materialien für digitales Lernen und onlineKommunikation. Psychologie in Erziehung und Unterricht, 68 (1), 23-41. Retrieved from: http://dx.doi.org/10.2378/peu2021.art01d

Milrud R. P. (2016). Kul'turnoe samoopredelenie lichnosti kak problema inoyazychnogo obrazovaniya [Cultural self-determination of the individual as a problem of foreign language education]. Nauchnyj dialog [Scientific dialogue],2 (50), 404-415. Retrieved from: https://www.elibrary.ru/item.asp?id=25510015

Sadokhin A.P. (2004). Mezhkul'turnaya kommunikaciya. Ucheb. posobie po discipline "Kul'turologiya" [Intercultural Communication. Textbook. manual on the discipline "Culturology"]. M.: Alfa-M: INFRA-M, Retrieved from: https://www.elibrary.ru/item.asp?id=19654767

Safonova, V.V. (2014). Soizuchenie yazykov i kul'tur v zerkale mirovyh tendencij razvitiya sovremennogo 
yazykovogo obrazovaniya [Co-Learning of languages and cultures in the mirror of world tendencies in developing modern language education]. Yazyk $i$ kul'tura [Language and culture], 1 (25), 123141. Retrieved from: https://elibrary.ru/item.asp?id=21371386

Savankova E.V., Hosainova O.S., Chigasheva M.A. (2020). Opyt distancionnogo prepodavaniya nemeckogo yazyka v MGIMO po dopolnitel'noj obrazovatel'noj programme: predstavleniya i real'nost' [Experience of distance teaching of German at MGIMO for an additional educational program: ideas and reality]. Inostrannye yazyki $v$ shkole [Foreign languages at school], 9, 50-56. Retrieved from: https://www.elibrary.ru/item.asp?id=43961974

Senkbeil, M. (2017). Profiles of computer-related motivations: Relations with ICT literacy and socioeconomic status. Results of the international school assessment study ICILS 2013 [Profile computerbezogener Anreizfaktoren: Zusammenhänge mit ICT Literacy und sozialen Herkunftsmerkmalen: Ergebnisse aus der internationalen Schulleistungsstudie ICILS 2013]. Psychologie in Erziehung und Unterricht, 64(2), 138-155. Retrieved from: http://dx.doi.org/10.2378/peu2017.art07d

Severova N.Y., Myuller Y.E. (2020). Didakticheskie vozmozhnosti cifrovyh resursov v obuchenii nemeckomu yazyku. [Didactic possibilities of digital resources in teaching German]. Inostrannye yazyki $v$ shkole [Foreign languages at school], 7, 38-4. Retrieved from: https://www.elibrary.ru/item.asp?id=43461588

Shamov, A. N., Guseva, L. V. (2017). The role of evaluation tools kit in recording of foreign language learning results. Linguistic and Cultural Studies: Traditions and Innovations, 677, 203-209. Retrieved from: https://doi.org/10.1007/978-3-319-67843-6_25

Sysoyev, P.V. (2015). Napravleniya informatizacii lingvisticheskogo obrazovaniya na sovremennom etape [Direktions of linguistic education informatization]. Yazyk $i$ kul'tura [Language and Culture], 1 (5), 63-74. Retrieved from: https://doi.org/10.17223/19996195/29/17

Tareva, E. G., \& Tarev, B. V. (2018). The assessment of students' professional communicative competence: New challenges and possible solutions. XLinguae, 11(2), 758-783. Retrieved from: https://doi.org/10.18355/XL.2018.11.02.59

Tretyakova, O. V., Karakozov, S. D., Voevoda, E. V. (2019). Media consumption trends in russia under digitalization. Media Watch, 10 (2), 197-211. Retrieved from: 
https://doi.org/10.15655/mw/2019/v10i2/49629

Voss, T., Wittwer, J. (2020). Teaching in times of corona: a look at the challenges from the perspective of research on learning and instruction [Unterricht in Zeiten von Corona: Ein Blick auf die Herausforderungen aus der Sicht von Unterrichts- und Instruktionsforschung]. Unterrichtswissenschaft, 48 (4), 601-627. Retrieved from: https://doi.org/10.1007/s42010-02000088-2 